\title{
Penegakan Hukum terhadap Tindak Pidana di Bidang Pengukuran
}

\author{
Titie Yustisia Lestari, Ridwan Tahir, Andi Afdhalia Sri Hayati \\ Fakultas Hukum Universitas Tadulako \\ Correspondence email: titieyustisia@ hotmail.com
}

\begin{abstract}
Abstrak. Dalam lalu lintas perdagangan dan transaksi jual-beli, alat ukur, takaran, dan timbangan merupakan salah satu sarana yang sangat vital dan amat diperlukan dalam menunjang terwujudnya suatu transaksi barang dan jasa. Kegunaannya, tidak lain adalah menentukan satuan dan bobot barang dan jasa yang menjadi objek perdagangan dan transaksi jual-beli tersebut.Untuk itu, dalam setiap transaksi jual-beli, khususnya perdagangan barang, dibutuhkan alat ukur, takaran, dan timbangan yang memenuhi standar metrologi legal atau legal metrology atau metrologie legale. Artinya, alat ukur, takaran, dan timbangan yang digunakan dalam setiap transaksi, haruslah memiliki legalitas dan keabsahan dari instansi yang diberi kewenangan untuk itu, yakni dari pihak Metrologi Legal atau Unit Pelaksana Teknis (UPT) Metrologi yang mengemban tugas-tugas kemetrologian yang berada di tingkat Provinsi dan Kabupaten/Kota. Penelitian ini adalah penelitian empiris yang dilaksanakan di kota Palu dengan menggunakan metode wawancara dan kuesioner. Hasil penelitian menunjukkan bahwa masih banyak pelanggaran yang dilakukan oleh Metrologi Legal bermula dari kebutuhan untuk menjamin keadilan dalam perdagangan, khususnya di bidang pengukuran dan penimbangan. Metrologi legal terutama berkaitan dengan alat-alat ukur yang diatur oleh Undang-Undang. Penyimpangan tindak pidana metrologi legal di kalangan pedagang banyak terjadi dikarenakan kesadaran hukum yang kuran dan ketidaktahuan mengenai undang-undang yang mengatur tentang metrologi legal.Faktor penghambat penegakan hukum terhadap tindak pidana metrologi legal antara lain kurangnya kesadaran masyarakat mengenai hukum itu sendiri dan kurangnya sosialisasi tentang ancaman pidana terhadap penyalahgunaan metrologi legal.
\end{abstract}

Kata Kunci: metrologi ilegal, pasar tradisional, pelanggaran metrologi

\begin{abstract}
In trade traffic and buying and selling transactions, measuring instruments, measurements, and scales are one of the most vital and necessary facilities in supporting the realization of a transaction of goods and services. Its purpose is to determine the unit and weight of the goods and services which are the object of the trade and the transaction. For that reason, in every trade transaction, especially trade in goods, measurement tools, measurements and scales that meet legal metrology standards are needed. or legal metrology or legale metrology. This means that the measurement tools, measurements, and scales used in each transaction must have the legality and validity of the agency that is authorized to do so, namely from the Legal Metrology or Metrology Technical Implementation Unit (UPT) which carries out the metrological tasks residing in Provincial and Regency / City level. This research is an empirical study conducted in the city of Palu using the interview and questionnaire method. The results showed that there were still many violations committed by Legal Metrology starting from the need to guarantee fairness in trade, especially in the area of measurement and weighing. Legal metrology is mainly concerned with measurement tools regulated by law. Irregularities in legal metrology among traders often occur due to lack of legal awareness and ignorance of the laws governing legal metrology. Factors inhibiting law enforcement against legal metrology criminal acts include a lack of public awareness about the law itself and a lack of socialization about threats criminal offenses against legal metrology abuse.
\end{abstract}

Keywords: illegal metrology, traditional markets, metrological violations

\section{PENDAHULUAN}

Perilaku pedagang atau penjual yang demikian itu, tujuannya hanyalah satu, yakni untuk mengejar keuntungan yang sebesar-besarnya dan sebanyak-banyaknya dengan cara yang tidak patut dan tidak legal. Praktik semacam ini, ditengarai masih saja terjadi setiap saat, terutama pada transaksi barang kebutuhan pokok rumah tangga sehari-hari yang terjadi di berbagai tempat perbelanjaan, terutama di pasar-pasar tradisional $^{1}$.

Praktik-praktik curang dalam penggunaan alat ukur, takaran, dan timbangan itu, sudah barangtentu dapat merugikan pihak-pihak tertentu. Modus dan cara seperti itu, dipastikan berdampak langsung kepada salah satu pihak yang melakukan transaksi, yakni pembeli ataupun penjual sebagaimana diuraikan di atas.

${ }^{1}$ Berdasarkan Pasal 1 Ayat (2) Peraturan Presiden Republik Indonesia Nomor. 112 Tahun 2007 tentang Penataan dan Pembinaan Pasar Tradisional, Pusat Perbelanjaan dan Toko Modern diartikan bahwa, Pasar Tradisional adalah pasar yang dibangun dan dikelola oleh Pemerintah, Pemerintah Daerah, Swasta, Badan Usaha Milik Negara dan Badan Usaha Milik Daerah termasuk kerjasama dengan swasta dengan tempat usaha berupa toko, kios, los dan tenda yang dimiliki/dikelola oleh pedagang kecil, menengah, swadaya masyarakat atau koperasi dengan usaha skala kecil, modal kecil dan dengan proses jual beli barang dagangan melalui tawar menawar. 
Selanjutnya, jika praktik kecurangan itu berlangsung cukup lama, maka akumulasi kerugian yang ditimbulkan semakin besar yang pada gilirannya tentu sangat merugikan masyarakat selaku konsumen.

Padahal, terkait dengan penyalahgunaan atau praktik curang dalam penggunaan takaran dan timbangan tersebut, Kitab Suci Al-Qur'an, yang diturunkan oleh Allah SWT sekian abad yang lalu sudah menegaskan bahwa:

Kecelakaan besarlah bagi orang-orang yang curang. (Yaitu) orang-orang yang apabila menerima takaran dari orang lain, mereka minta dipenuhi. Dan apabila mereka menakar atau menimbang untuk orang lain, mereka mengurangi. Tidakkah orang-orang itu yakin bahwa sesungguhnya mereka akan dibangkitkan. Pada suatu hari yang besar. (Yaitu) hari (ketika) manusia berdiri menghadap Rabb semesta alam. ${ }^{2}$

Kondisi sebagaimana dipaparkan di atas, disinyalir terjadi di mana-mana di seluruh Indonesia, tidak terkecuali di Wilayah Kota Palu, Ibukota Provinsi Sulawesi Tengah, di mana di daerah ini, berdasarkan infomrasi yang diperoleh dari Dinas Perdagangan dan Perindustrian Kota Palu, hingga tahun 2018 ini, terdapat sedikitnya 6.000-an Alat Ukur, Takaran, Timbangan, dan Perlengkapannya (UTTP), di mana peralatan tersebut, setiap harinya digunakan secara aktif dalam transaksi jual-beli.

Pihak Dinas Perdagangan dan Perindustrian Kota Palu pun telah menjadikan salah satu sasaran program "tera" dan "tera ulang", agar UTTP yang ada di daerah ini, memiliki legalitas dalam penggunaanya dan diharapkan pula dari program itu, menurut informasi yang diperoleh dari Kepala Bidang Perdagangan, Dinas Perdagangan dan Perindustrian Kota Palu, Amiruddin, S.H., M.M. setiap transaksi jualbeli yang menggunakan UTTP tidak menimbulkan dampak dan kerugikan bagi siapa saja, khususnya para konsumen ${ }^{3}$.

Berdasarkan informasi tersebut di atas, di mana diperkirakan terdapat sekitar 6.000-an UTTP yang aktif digunakan dalam setiap transaksi di kota ini, namun pengguna yang memenuhi panggilan untuk mengikuti Sidang Tera Ulang pada tahun 2017 lalu, jumlahnya hanya sekitar 1.500 orang. Padahal, menurut Kepala Unit Pelaksana Teknis (UPT) Metrologi, Dinas Perdagangan dan Perindustrian Kota Palu, Nafian, S.T., pelaksanaan Sidang Tera Ulang tersebut, sengaja ditempatkan pada sejumlah lokasi di Kota Palu, khususnya pada lingkungan pasar-pasar tradisional, agar para pengguna UTTP itu mudah menjangkaunya. ${ }^{4}$

Mencermati data dan informasi di atas, ditengarai atensi pengguna UTTP untuk melakukan tera dan tera ulang di daerah ini, terbilang masih cukup rendah. Padahal, keengganan atau pun ketidakmauan para pengguna UTTP untuk melakukan tera dan tera ulang UTTP yang digunakannya dalam setiap transaksi jualbeli, merupakan perbuatan yang dapat dikualifikasi sebagai suatu tindak pidana, baik berupa kejahatan dibidang pengukuran, sebagaimana diatur dalam Pasal 32 Ayat (1) dan (2), maupun pelanggaran dibidang penggunaan alat ukur, takaran, dan timbangan, sebagaimana diatur dalam Pasal 32 Ayat (3) Undangundang Nomor. 2 Tahun 1981 tentang Meterologi Legal.

Disamping kualifikasi tindak pidana sebagaimana disebutkan di atas, perbuatan para pengguna UTTP yang berlaku curang atau menyalahgunakan alat ukur, takaran, dan timbangan yang dimilikinya dalam perdagangan atau transaksi jual-beli barang, sudah barangtentu pula menyebabkan terjadinya kerugian di pihak lain, khususnya bagi para konsumen, sehingga atas perbuatan itu, pelakunya dapat pula dikualifikasi telah melakukan kejahatan dibidang perlindungan konsumen, berdasarkan Undang-undang Nomor. 8 Tahun 1999 tentang Perlindungan Konsumen.

Terhadap kondisi sebagaimana dipaparkan di atas, setidaknya aspek pengawasan dari pemerintah dan tindakan lain, berupa penyuluhan, upaya pembinaan, dan penegakan hukum atas dugaan praktik curang penggunaan alat ukur, takar, dan timbangan itu sangat diperlukan. Tujuannya, tidak lain demi memberi perlindungan dan jaminan kepastian penggunaan alat ukur, takar, dan timbangan yang legal kepada masyarakat Kota Palu.

Pentingnya aspek pengawasan terhadap alat ukur, takaran, dan timbangan itu, diakui Direktur Metrologi, Direktorat Jenderal Perlindungan Konsumen dan Tertib Niaga, Kementerian Perdagangan Republik Indonesia, Hari Prawoko. Menurutnya, pengawasan metrologi legal merupakan salah satu "ujung

\footnotetext{
${ }^{2}$ Qur'an Surah. Al-Muthaffifîn/83:1-6.

3 Hasil wawancara penulis dengan Kepala Bidang Perdagangan, Dinas Perdagangan dan Perindustrian Kota Palu, Amiruddin, S.H., M.M., pada Senin, 23 April 2018, di Palu;

${ }^{4}$ Hasil wawancara penulis dengan Kepala Unit Pelaksana Teknis (UPT) Metrologi Dinas Perdagangan dan Perindustrian Kota Palu, Nafian, S.T., pada Senin, 23 April 2018, di Palu.
} 
tombak" dalam penegakan hukum dibidang metrologi legal. Selanjutnya Prawoko mengingatkan bahwa, dalam ketentuan Pasal 36 Undang-Undang Nomor 2 Tahun 1981 tentang Metrologi Legal, diamanatkan pula kepada segenap pegawai instansi pemerintah yang ditugaskan dalam pembinaan untuk senantiasa melaksanakan pengawasan dan pengamatan. Selain itu, pegawai instansi pemerintah yang diberi kewenangan untuk itu, juga diwajibkan untuk menyidik tindak pidana yang ditentukan dalam undangundang tersebut ${ }^{5}$.

Atas penegasan Direktur Metrologi tersebut, maka sesungguhnya aspek penegakan hukum dibidang metrologi legal, tidak bisa dikesampingkan, diremehkan, atau pun ditunda untuk tidak dilaksanakan sebagaimana mestinya dengan berbagai alasan dan dalih yang sifatnya hanyalah sebagai pembenaran belaka ${ }^{6}$. Misalnya terbatasnya dana dan tidak memadainya jumlah tenaga yang membidangi masalah itu.

Penegakan hukum dibidang ini, tentu sangat diharapkan oleh masyarakat, khususnya masyarakat Kota Palu, sebab jika hal itu tidak dilakukan, maka sudah barangtentu pula menimbulkan kesan yang tidak baik, karena tidakan untuk "tidak" atau "menunda" proses penegakan hukum atas kejahatan dan pelanggaran dibidang metrologi legal ini, nuansanya akan bermuara pada dugaan tentang adanya unsur "kesengajaan" dari aparat pemerintah yang membidangi tugas itu, untuk melakukan "pembiaran" atas terjadinya praktik curang atau pun penyalahgunaan.

\section{METODE PENELITIAN}

\section{Lokasi Penelitian}

Penelitian ini akan dilaksanakan di Wilayah Kota Palu, Ibukota Provinsi Sulawesi Tengah. Adapun pertimbangan untuk menjadikan Kota Palu sebagai lokasi penelitian, adalah kota ini merupakan kota perdagangan yang memiliki jumlah penduduk dan tempat perbelanjaan, baik pasar tradisional/pasar rakyat, maupun pasar moderen terbesar di seluruh WilayahProvinsi Sulawesi Tengah ${ }^{7}$.

\section{Populasi dan Sampel}

Adapun populasi dari penelitian ini adalah seluruh pedagang barang kebutuhan pokok rumah tangga sehari-hari, yang menawarkan barang dagangannya di pasar-pasar tradisional, toko dan kios yang ada di Wilayah Kota Palu, yang dalam transaksi jual-belinya menggunakan takaran dan timbangan. Sedangkan sampel atau responden penelitian ini, adalah pedagang barang kebutuhan pokok rumah tangga sehari-hari, yang dipilih secara acak yang ada pada:

a. Pasar Inpres Manonda;

b. Pasar Masomba; dan

c. Pasar Mamboro;

d. Kios dan Toko.

Masing-masing dipilih sebanyak 10 orang pedagang setiap pasar, serta sebanyak 20 orang pemilik toko dan kios yang tersebar di Wilayah Kota Palu sebagai responden.

Disamping menggunakan responden, penelitian ini juga akan menjadikan sejumlah pihak sebagai informan, terutama pejabat di lingkungan Dinas Perdagangan dan Perindustrian Kota Palu, termasuk pejabat dan staf di lingkungan UPT Metrologi, Dinas Perdagangan dan Perindustrian Kota Palu, Penyidik Kepolisian pada Kepolisian Resort (Polres) Palu, dan para aktivis Lembaga Swadaya Masyarakat (LSM) yang bergerak dibidang perlindungan konsumen, serta kalangan lainnya yang peduli dengan persoalan tersebut.

5 Penegasan Hari Prawoko, disampaikan dalam Forum Pengawasan Metrologi Legal Nasional, Rabu (26/4) 2017, di Hotel Mercure, Bandung. Dikutip dari http://www.hukumonline.com/berita/baca/ lt5901c04e277e9/ pengawasan-jadi-ujungtombak-penegakan-hukum-metrologi-legal, Selasa, 24 April 2018.

${ }^{6}$ Khusus yang terjadi di Kota Palu, timbul kesan adanya " pembiaran" atas kejahatan di bidang Metrologi Legal ini, karena sejauh ini belum ada informasi tentang adanya oknum pedagang atau pengguna takaran dan timbangan yang diproses secara hukum, berdasarkan ketentuan hukum yang ada.

${ }^{7}$ Di Wilayah Provinsi Sulawesi Tengah, hingga tahun 2016 lalu, memiliki sekitar 300 Pasar Tradisional/Pasar Rakyat, tersebar di seluruh kabupaten/kota, dikutip dari https://sulteng.antaranews.com/berita/30109/ sulteng-miliki-300-pasar-rakyat, tanggal 16 April 2018. 


\section{Teknik Pengumpulan Data}

Untuk mendapatkan data valid guna menjawab permasalahan dan tujuan penelitian ini, peneliti terlebih dahulu melakukan penelusuran pustaka atau studi pustaka, khususnya bahan-bahan pustaka atau referensi yang terkait dan memiliki relevansi dengan topik penelitian ini. Selain itu, untuk memperoleh data dan informasi secara mendalam, dilakukan pula observasi dan wawancara.

a. Observasi, pengumpulan data dengan menggunakan teknik ini, yakni peneliti melakukan pengamatan secara langsung di lokasi penelitian dengan fokus pengamatan ditujukan kepada cara para responden melakukan penakaran dan penimbangan barang yang jual kepada pembeli;

b. Wawancara, pengumpulan data dengan menggunakan teknik ini, yakni peneliti melakukan tanya-jawab atau interview secara langsung kepada para responden. Guna menjaga konsistensi topik dan materi wawancara tersebut, peneliti menggunakan pedoman atau panduan wawancara yang terlebih dahulu disiapkan, sehingga pertanyaan yang diajukan kepada para responden tersebut, terarah dan memiliki kesamaan topik dan materi pertanyaan. Wawancara juga dilakukan peneliti kepada para informan, sesuai dengan bidang tugas, keahlian, dan kapasitasnya masing-masing.

\section{Analisis Data}

Data lapangan yang diperoleh dianalisis dengan menggunakan metode Analisis Deskriptif, sehingga analisis yang dihasilkan akan mengungkap gambaran atau deskripsi tentang prosedur pengawasan dan penegakan hukum terhadap kejahatan dan pelanggaran penggunaan takaran dan timbangan di Kota Palu.

Disamping itu, berdasarkan metode ini, juga akan memberi gambaran atau deskripsi tentang upaya penanggulangan kejahatan dan pelanggaran praktik curang penggunaan takaran dan timbangan yang digunakan para pedagang, khususnya pedagang pada pasar tradisional yang ada di Kota Palu.

\section{HASIL DAN PEMBAHASAN}

Pelaksanaan Pengawasan Dinas Perindustrian Dan Perdagangan Terhadap Penerapan Ukuran, Takaran, Timbangan Dan Perlengkapannya (UTTP) Pada Pedagang Pasar Tradisional Kota Palu

Penerapan dari sebuah Undang-Undang merupakan suatu hal yang sangat penting, karena suatu Undang-Undang akan memberikan suatu kepastian hukum apabila Undang-Undang tersebut mampu memberikan efek yang positif bagi masyarakat termasuk dalam menangani suatu permasalahan konsumen secara umum. Berikut ini merupakan data yang penulis peroleh melalui angket dan dapat dilihat pada tabel 1 sebagai berikut:

Tabel 1. Pengetahuan Pelaku Usaha Dan Konsumen Terhadap Undang-Undang Perlindungan Konsumen

\begin{tabular}{llll}
\hline No & Jawaban Responden & Jumlah & Persentase \\
\hline 1 & Mengetahui & 21 & $43.75 \%$ \\
2 & Tidak mengetahui & 7 & $14.59 \%$ \\
3 & Baru mengetahui & 20 & $41.66 \%$ \\
Jumlah & 48 & $100 \%$ \\
\hline
\end{tabular}

Sumber: Data yang diolah pada bulan Juli-Agustus 2018

Dilihat dari tabel diatas dapat diketahui bahwa dari 48 responden yang menjawab mengetahui ada 21 responden dengan persentase $43.75 \%$ dan yang menjawab tidak mengetahui ada 7 responden dengan persentase $14.59 \%$ serta yang menjawab baru mengetahui ada 20 responden dengan persentase $41.66 \%$. Ini membuktikan bahwa pelaku usaha dan konsumen Pasar Tradisional Kota Palu mengetahui bahwa adanya Undang-Undang tentang Perlindungan Konsumen meskipun masih ada dari sebagian besar konsumen yang baru mengetahui Undang-Undang ini.

Dalam rangka mewujudkan perlindungan terhadap kepentingan konsumen yang telah dijamin oleh undang-undang, maka pemerintah sebagai aparat penegak hukum memberikan pelayanan bidang perlindungan konsumen:

a. Bidang kemetrologian berupa realisasi kemetrologian sebagai upaya pelaksanaan pelayanan tera dan tera ulang alat UTTP milik pengusaha dan pedagang. 
b. Bidang perlindungan konsumen berupa pemberian pelayanan dan penanganan fasilitasi penyelesaian sengketa konsumen dengan pembinaan dan pemberdayaan motivator dan mediator perlindungan konsumen.

Atas jaminan kebenaran hasil pengukuran untuk mencapai tujuan sebagaimana diamanatkan dalam Undang-Undang Nomor 2 Tahun 1981 tentang Metrologi Legal, maka dalam menata dan membina penggunaan Ukuran, Takaran, Timbangan dan Perlengkapannya (UTTP) Dinas Perindustrian dan Perdagangan (Disperindag) melakukan pengawasan terhadap Penerapan UTTP berdasarkan Peraturan Pemerintah Nomor 38 Tahun 2007 tentang Pembagian Urusan Pemerintah Antara Pemerintah Daerah Provinsi dan Pemerintah Daerah Kabupaten/Kota serta Peraturan Menteri Perdagangan RI Nomor 50/MDAG/PER/10/2009 Tentang Unit Kerja dan Unit Pelaksana Teknis (UPT) Metrologi Legal.

Untuk melindungi agar tidak ada pihak yang dirugikan akibat dari pemakaian alat-alat Ukur, Takar, Timbang atau Perlengkapannya yang tidak memenuhi kebenaran, kepekaan dan ketepatan penunjukannya, berdasarkan Peraturan Menteri Perdagangan RI Nomor 50/M-DAG/PER/10/2009 Tentang Unit Kerja dan Unit Pelaksana Teknis (UPT) Metrologi Legal maka Dinas Perindustrian dan Perdagangan Pemerintahan Kota Palu bidang Perdagangan Seksi usaha Pedagang dan Metrologi melakukan pengawasan secara terus menerus dan berkesinambungan. Pengawasan Disperindag untuk memeriksa setiap alat UTTP, mulai dari pelaksanaan pengawasan UTTP Perusahaan, Pedagang Pasar, Toko/Kios/Warung/Kaki 5, dan Pengawasan wajib tera dan tera ulang Perusahaan, Pedagang Pasar, Toko/ Kios/ Warung/Kaki 5.

Pengawasan Kemetrologian sebagai tugas pokok unit kerja terhadap Alat Ukur, Takar, Timbang, dan Perlengkapannya (UTTP), Barang Dalam Keadaan Terbungkus (BDKT), dan Satuan Sistem Internasional (SI)/ Satuan Ukur. Pengawasan Kemetrologian dilaksanakan secara bersama-sama yang tergabung dalam Tim Terpadu Pengawasan Alat Ukur Kota Palu yang terdiri dari unsur Disperindag Provinsi Sulawesi Tengah, Poltabes Kota Palu, Satpol PP Kota Palu, Dinas Perhubungan Kota Palu dan Disperindag Kota Palu.

Dalam meningkatkan peranan Dinas Perindustrian dan Perdagangan Kota Palu telah dilakukan beberapa upaya dalam melakukan tugas pengawasan untuk mewujudkan tertib UTTP dengan pelaksanaan kegiatan layanan informasi konsumen. Adapun kegiatan yang dilakukan dalam upaya meningkatkan pemahaman di bidang metrologi legal antara lain: Membuka pelayanan tera dan tera ulang timbangan, penyediaan pos ukur ulang, dan penggantian timbangan plastik ketimbangan pegas.

Berlakunya Undang-Undang Nomor 8 Tahun 1999 Tentang Perlindungan Konsumen, diharapkan dapat mendidik masyarakat Indonesia untuk lebih menyadari akan hak dan kewajiban baik sebagai pelaku usaha maupun konsumen ${ }^{8}$. Sebagaimana yang tercantum dalam konsideran undang-undang Nomor 8 Tahun 1999 tentang Perlindungan Konsumen yang menyatakan bahwa untuk meningkatkan harkat dan martabat konsumen perlu ditingkatkan kesadaran dan kemandirian konsumen untuk melindungi dirinya serta menumbuh kembangkan pelaku usaha yang bertanggung jawab.

Tentu saja jika undang-undang itu ditaati oleh sebagian besar target yang menjadi sasaran ketaatan, maka bisa dikatakan bahwa suatu undang-undang tersebut dapat diterapkan terhadap masyarakat maupun pihak pihak yang bersangkutan, yang diatur langsung oleh Undang-Undang tersebut. Diantaranya mengenai larangan pelaku usaha yang terdapat dalam Undang-Undang Perlindungan Konsumen hal ini dapat dilihat pada tabel dibawah ini:

Tabel 2. Larangan Bagi Pelaku Usaha Dalam Transaksi Jual Beli

\begin{tabular}{llll}
\hline No & Jawaban Responden & Jumlah & Persentase \\
\hline 1 & Mengetahui & 11 & $68.75 \%$ \\
2 & Tidak mengetahui & 5 & $31.25 \%$ \\
& $\quad$ Jumlah & 16 & $100 \%$ \\
\hline
\end{tabular}

Sumber: Data yang diolah pada bulan Juli-Agustus 2018

Dari tabel diatas dapat dilihat bahwa dari 16 responden, yang menjawab mengetahui ada 11 responden dengan persentase $68.75 \%$ dan yang menjawab tidak mengetahui ada 5 responden denga persentase $31.25 \%$.

\footnotetext{
${ }^{8}$ Gunawan Widjaja, Hukum Tentang Perlindungan Konsumen, (Jakarta: PT. Gramedia Pustaka Utama, 2001), h. 2.
} 
ini membuktikan bahwa sebagian besar dari pelaku usaha Pasar Tradisional Palu mengetahui hal-hal yang dilarang bagi mereka dalam menjalankan usaha mereka. Sebaliknya bagi konsumen selain dari hak juga harus memenuhi kewajibannya sebagaimana dapat dilihat pada tabel dibawah ini:

Tabel 3. Kewajiban Konsumen Dalam Transaksi Jual Beli

\begin{tabular}{llll}
\hline No & Jawaban Responden & Jumlah & Persentase \\
\hline 1 & Mengetahui & 25 & $78.13 \%$ \\
2 & Tidak mengetahui & 7 & $21.87 \%$ \\
& Jumlah & 32 & $100 \%$ \\
\hline
\end{tabular}

Sumber: Data yang diolah pada bulan Juli-Agustus 2018

Dari tabel diatas dapat dilihat sebanyak 25 responden dengan persentase $78.13 \%$ yang menjawab mengetahui dan sebanyak 7 responden dengan persentase $21.87 \%$ yang menjawab tidak mengetahui. Ini membuktikan bahwa sebagian besar dari konsumen Pasar Tradisional Palu mengetahui kewajiban mereka sebagai konsumen.

Untuk melindungi kepentingan umum/konsumen perlu adanya jaminan dalam kebenaran pengukuran serta adanya ketertiban dan kepastian hukum dalam pemakaian satuan ukuran, standar satuan, metoda pengukuran dan alat-alat ukur, takar, timbang dan perlengkapannya (UTTP) dalam transaksi jual beli pada pedagang pasar Tradisional Palu, maka dapat kita lihat pada pemenuhan atas hak-hak konsumen yang terdapat dalam Undang-Undang Nomor 8 Tahun 1999 Tentang Perlindungan Konsumen garis besar dapat dilihat dibawah ini:

\section{Mendapatkan barang sesuai dengan UTTP}

Hak ini dimaksud untuk melindungi konsumen dari kerugian akibat pelaku usaha yang berbuat curang atas barang dagangannya serta permainan harga secara tidak wajar. Kondisi dan fenomena tersebut dapat mengakibatkan kedudukan pelaku usaha atau para pedagang dan konsumen menjadi tidak seimbang dan konsumen berada pada posisi lemah.

Faktor utama yang menjadi kelemahan konsumen adalah tingkat kesadaan konsumen akan haknya masih rendah. Hal ini terutama disebabkan kurangnya pengetahuan konsumen terhadap Undang-Undang Perlindungan Konsumen pun menjadi salah satu masalah karena konsumen tidak mengetahui dan mengerti isi Undang-Undang tersebut serta kurangnya perhatian pemerintah terhadap konsumen. Berdasarkan hasil angket penulis tentang transaksi jual beli dalam mendapatkan barang sesuai dengan nilai tukar dapat dilihat pada tabel dibawah ini:

Tabel 4. Hak Mendapatkan Barang Sesuai Dengan UTTP

\begin{tabular}{llll}
\hline No & Jawaban Responden & Jumlah & Persentase \\
\hline 1 & Ya & 15 & $46.87 \%$ \\
2 & Tidak & 17 & $53.13 \%$ \\
& Jumlah & 32 & $100 \%$ \\
\hline
\end{tabular}

Sumber: Data yang diolah pada bulan Juli-Agustus 2018

Dari tabel di atas dapat dilihat dari keseluruhan responden yang menyatakan tentang hak untuk mendapatkan barang sesuai dengan nilai tukar, sebanyak $46.87 \%$ atau setara dengan 15 orang responden yang menjawab ya sedangkan sebanyak $53.13 \%$ atau setara dengan 17 orang responden yang menjawab tidak mendapatkan barang sesuai dengan nilai tukar. Hal ini membuktikan bahwa masih ada pelaku usaha yang tidak menjalankan kewajibannya untuk memenuhi hak konsumen.

Berdasarkan wawancara Penulis kepada bapak Sudirman ${ }^{9}$ menyatakan bahwa ruang lingkup dari kegiatan metrologi legal terdapat dua sisi Pembinaan/Pengawasan dan sisi Pelaksanaan/Teknik. Pertama Kegiatan Pembinaan/Pengawasan dilakukan oleh unit kerja metrologi legal yang meliputi :

a. Penyuluhan dan pengamatan Alat Ukur, Takar, Timbangan dan Perlengkapannya (UTTP), Barang dalam Keadaan Terbungkus (BDKT), dan Satuan Sistem Internasional (SI).

\footnotetext{
${ }^{9}$ Staf Dinas Perindustrian dan Perdagangan Kota Palu
} 
b. Pengawasan Alat Ukur, Takar, Timbangan dan Perlengkapannya (UTTP), Barang dalam Keadaan Terbungkus (BDKT), dan Satuan Sistem Internasional (SI) serta penyidikan tindak pidana dibidang metrologi legal.

Kedua kegiatan pelaksana/teknik dilakukan oleh Unit Pelaksana Teknis Daerah (UPTD) Metrologi yang meliputi:

a. Pengelolaan standar ukuran dan laboratorium

b. Pengujian UTTP dalam rangka izin tipe dan izin tanda pabrik

c. Pelaksanaan tera dan tera ulang UTTP

Maksud dan tujuan pelaksanaan Kegiatan ini adalah untuk terlaksananya pembinaan dan pengawasan terhadap metrologi legal dan mendorong terbentuknya unit teknis kemetrologian ditingkat daerah sebagai wujud nyata dari amanat undang-undang nomor 2 tahun 1981 tentang metrologi legal dalam rangka perlindungan konsumen kepada masyarakat baik terhadap produsen terlebih lagi terhadap konsumen selaku pengguna barang dan jasa untuk dikonsumsi dan sebagai bahan baku industri sehingga dapat terciptanya tertib ukur disemua sektor perekonomian yang pada gilirannya dapat mendorong tumbuh dan berkembangnya investasi di suatu wilayah.

Berdasarkan ruang lingkup dari kegiatan metrologi legal diatas bapak Sudirman menjelaskan bahwa untuk saat ini pengawasan Disperindag Kota Palu lebih menfokuskan kepada UTTP dengan skala besar seperti SPBU, namun tidak berarti pengawasan pada pasar tradisional tidak dilakukan. Pengawasan pada pasar tradisional tetap dilakukan berdasarkan atas program kerja dan laporan.

Hasil wawancara penulis pada hari Minggu 14 Juli 2018 kepada tiga orang pelaku usaha atau para pedagang Pasar Masomba, yang mana secara garis besar dari pedagang menyatakan bahwa konsumen yang membeli barang kepada mereka akan mendapatkan barang sesuai dengan yang dijanjikan tanpa menyembunyikan kecacatan barang tersebut.

Selanjutnya berdasarkan wawancara penulis pada hari Minggu 14 Juli 2018 kepada salah seorang dari konsumen yang menyatakan tidak mendapatkan barang sesuai dengan UTTP. "Ini disebabkan pengalaman kami yang membeli barang yang tadinya kami lihat bagus ternyata sudah dicampur dengan barang lama serta terdapat praktek kecurangan dengan manipulasi timbangan. "Ketika kami cek dan ditimbang kembali, sepertinya buah alpokat yang kami beli senilai $5 \mathrm{~kg}$ ternyata tidak sesuai dan beratnya kurang hampir 0,5kg". Padahal kami telah memenuhi kewajiban dengan membayar sesuai dengan kesepakatan.

Praktek transaksi jual beli yang dilakukan oleh pelaku usaha ini tentunya sudah menyalahi peraturan perundang-undangan, yang mana didalam Undang-Undang No. 8 Tahun 1999 tentang Perlindungan Konsumen, bab IV perbuatan yang dilarang bagi pelaku usaha didalam pasal 8 ayat (1) huruf b dan c, yang menyatakan bahwa pelaku usaha dilarang memproduksi dan/atau memperdagangkan barang dan/atau jasa yang tidak sesuai dengan berat bersih, isi bersih atau netto, tidak sesuai dengan ukuran, takaran, timbangan dan menurut ukuran yang sebenarnya.

Hasil wawancara penulis pada hari selasa 8 Oktober 2018, terkait masalah timbangan Dinas Perindustrian dan Perdagangan Kota Kota Palu, Bapak Sudirman menyatakan kepada pelaku usaha untuk tidak menggunakan timbangan plastik dan timbangan besi yang sudah dipenuhi dengan karat serta tidak layak pakai dalam melakukan transaksi perdagangan.

Larangan menggunakan timbangan plastik disebabkan timbangan plastik hanya diperbolehkan untuk pemakaian dalam skala rumah tangga, sementara untuk keperluan berdagang seharusnya menggunakan timbangan dari besi karena untuk dagangan kebanyakan yang ditimbang berat, dikhawatirkan akan banyak kesalahan dalam penimbangan dan juga larangan untuk tidak menggunakan timbangan dari besi dalam keadaan berkarat atau rusak, karena dipastikan dapat merubah akurasi timbangan sehingga untuk menimbang barang dagangan dipastikan akan salah.

Namun pada praktek dilapangan masih banyak ditemukan pelaku usaha yang yang menggunakan timbangan plastik. Kebanyakan dari mereka mengatakan lebih senang menggunakan timbangan plastik lantaran harganya terjangkau selain itu praktis untuk dibawa kemana-mana di pasar sedangkan timbangan besi harganya mahal.

Untuk menangkal kecurangan perdagangan, perlu dilakukan tera ulang timbangan guna memberikan perlindungan kepada konsumen atas praktek kecurangan pedagang. Dalam kegiatan tera, pedagang bisa mengecekkan timbangan jika merasa timbangannya kelebihan takaran. Memang tera ukuran, takaran, 
timbangan dan perlengkapannya dilakukan untuk menjamin kepastian agar pedagang dan masyarakat samasama tidak dirugikan. Jadi transaksi berjalan normal dan adil.

Oleh karena itu Undang-Undang Perlindungan Konsumen menjadi landasan hukum yang sangat kuat bagi pemerintah dan lembaga perlindungan konsumen swadaya masyarakat melalui pembinaan dan pendidikan konsumen karena konsumen berada pada posisi lemah. Upaya pemberdayaan ini penting karena tidak mudah mengharapkan kesadaran pelaku usaha, yang pada dasar prinsip ekonomi pelaku usaha adalah mendapatkan keuntungan yang semaksimal mungkin.

Para pelaku usaha akan melakukan apapun agar tujuan mereka tercapai meskipun bertentangan dengan undang-undang. Padahal didalam Undang-Undang Perlindungan Konsumen telah dijelaskan hak dan kewajiban antara konsumen dengan pelaku usaha, Namun tidak banyak pelaku usaha yang menjalankan kewajibannya. Prinsip ini sangat potensial merugikan kepentingan konsumen baik secara langsung maupun tidak langsung.

Hal ini merupakan tugas yang sangat berat untuk pemerintah. Seharusnya pemerintah langsung mengawasi seluruh kegiatan yang ada dipasar-pasar tradisional ataupun modern. Dengan cara menetapkan harga sesuai dengan standar yang ada dan memeriksa perlengkapan untuk berdagang apakah sudah sesuai standar ataukah belum. Sehingga para konsumen merasa tidak dirugikan lagi dengan para pedagangpedagang nakal. Itulah yang membuat penulis mengatakan bahwa pengawasan UTTP pada pedagang Pasar Tradisional Kota Palu belum diterapkan secara efektif. Karena masih banyaknya pegadang-pedagang yang belum berlaku jujur untuk mendapatkan keuntungan yang tinggi.

Menurut analisa penulis terhadap transaksi pasar yang dilakukan oleh pelaku usaha selain menyalahi aturan tentang Perlindungan Konsumen juga pelaku usaha juga melanggar undang-undang Metrologi Legal seharusnya pemerintah lebih memperketat pengawasan pada pelaku usaha dan memberi sanksi yang tegas atas pelanggaran agar menimbulkan efek jera bagi pelaku usaha.

2. Mendapatkan Informasi Yang Benar, Jelas, dan Jujur Dalam Transakai Jual Beli

Hubungan antara pelaku usaha/produsen (penghasil barang dan atau jasa) dengan konsumen (pemakai akhir dari barang dan atau jasa untuk diri sendiri atau keluarganya) merupakan hubungan yang terus menerus dan berkesinambungan. Hubungan tersebut terjadi karena keduanya memang saling menghendaki dan mempunyai tingkat ketergantungan yang cukup tinggi antara yang satu dengan yang lainnya ${ }^{10}$

Berikut ini merupakan data yang penulis peroleh melalui angket dan dapat dilihat pada tabel IV.1 sebagai berikut :

Tabel 5. Pengetahuan Pelaku Usaha Dan Konsumen Terhadap Ukuran, Takaran, Timbangan Dan Perlengkapannya (UTTP)

\begin{tabular}{llll}
\hline No & Jawaban Responden & Jumlah & Persentase \\
\hline 1 & Mengetahui & 39 & $81.25 \%$ \\
2 & Tidak mengetahui & 7 & $14.59 \%$ \\
3 & Baru mengetahui & 2 & $4.16 \%$ \\
& Jumlah & 48 & $100 \%$ \\
\hline
\end{tabular}

Sumber: Data yang diolah pada bulan Juli-Agustus 2018

Dilihat dari tabel di atas dapat diketahui bahwa dari 48 responden yang menjawab mengetahui ada 39 responden dengan persentase $81.25 \%$ dan yang menjawab tidak mengetahui ada 7 responden dengan persentase $14.59 \%$ serta yang menjawab baru mengetahui ada 2 responden dengan persentase $4.16 \%$. Ini membuktikan bahwa sebagian besar pelaku usaha dan konsumen Pasar Tradisional Kota Palu mengeahui UTTP.

Setiap transaksi yang dilakukan dalam perdagangan harus disertai informasi yang benar, jelas, dan jujur. Informasi ini diperlukan agar konsumen tidak sampai mempunyai gambaran keliru dalam membeli suatu produk. Seperti promosi secara lisan yang dilakukan para pedagang pasar tradisional untuk menarik hati konsumen.

${ }^{10}$ Sri Redjeki Hartono, Aspek-Aspek Hukum Perlindungan Konsumen Dalam Kerangka Era perdagangan Bebas, (Bandung : CV Mandar Maju, 2000), h. 36 
Hasil penyebaran angket penulis dengan responden berkaitan dengan informasi penjualan barang yang sesuai dengan UTTP menurut ukuran yang sebenarnya. Dimana jawaban responden dapat dilihat pada tabel dibawah ini:

Tabel 6. Pemberian Informasi Penjualan Barang Yang Sesuai Dengan UTTP

\begin{tabular}{cccc}
\hline No. & Jawaban Responden & Jumlah & Persentase \\
\hline 1 & Ya & 7 & $21.87 \%$ \\
2 & Tidak Tahu & 9 & $28.13 \%$ \\
3 & Tidak & 16 & $50 \%$ \\
& Jumlah & 32 & $100 \%$ \\
\hline
\end{tabular}

Sumber: Data yang diolah pada bulan Juli-Agustus 2018

Dari tabel diatas dapat dilihat bahwa dari keseluruhan reponden yang menyatakan mendapatkan informasi benar, jelas, dan jujur mengenai barang yang dijual para pedagang sesuai dengan UTTP menurut ukuran yang sebenarnya sebanyak 7 responden atau setara dengan $21.87 \%$, sebanyak 9 responden atau setara dengan $28.13 \%$ responden menjawab tidak tahu, sebanyak 16 responden atau setara dengan $50 \%$ responden menjawab tidak mendapatkan informasi benar, jelas, dan jujur mengenai barang yang dijual para pedagang yang sesuai dengan UUTP menurut ukuran yang sebenarnya.

Tabel 7. Menjual Barang Sesuai Dengan UTTP

\begin{tabular}{llll}
\hline No & Jawaban Responden & Jumlah & Persentase \\
\hline 1 & Ya & 4 & $25 \%$ \\
2 & Tidak & 1 & $6.25 \%$ \\
3 & Kadang-Kadang & 11 & 68.75 \\
& Jumlah & 16 & $100 \%$ \\
\hline
\end{tabular}

Sumber: Data yang diolah pada bulan Juli-Agustus 2018

Dari tabel diatas dapat dilihat bahwa dari 16 responden, ada 4 responden dengan persentase $25 \%$ yang menjawab ya dan ada 1 responden dengan persentase $6.25 \%$ yang menjawab tidak, serta ada 11 responden dengan persentase $68.75 \%$ kadang-kadang. Ini membuktikan bahwa masih ada pelaku usaha dalam melakukan transaksi perdagangan yang menjual barang tidak sesuai dengan UTTP serta melakukan hal-hal yang dilarang bagi pelaku usaha meskipun tidak menutup kemungkinan masih ada pelaku usaha yang jujur dalam bertransaksi.

Berdasarkan wawancara penulis pada hari Minggu tanggal 14 juli 2018 kepada salah seorang pelaku usaha menyatakan bahwa setiap pembeli yang memerlukan informasi berkaitan dengan UTTP dalam transaksi jual beli maka kami memberi informasi yang benar, jelas dan jujur. Karena kami sebagai penjual juga menjaga langganan kami supaya selanjutnya untuk tetap mau membeli barang yang kami jual, dengan menjaga agar tetap berlangganan maka kami akan memberi layanan berupa pemberian informasi yang benar dan jujur mengenai barang yang kami jual.

Lain halnya yang dikatakan oleh salah seorang konsumen yang menjawab tidak mendapatkan informasi yang benar, jelas, dan jujur, ia mengatakan bahwa seorang penjual akan dengan sendirinya mempromosikan jualannya kepada pembeli, karena tujuan mereka adalah lakunya jualan tersebut.

Berdasarkan wawancara penulis pada tanggal 08 Oktober 2018, kepada ketua Dinas Perindustrian Dan Perdagangan Kota Kota Palu menyatakan konsumen berhak mendapatkan informasi sesuai dengan kondisi barang, dan konsumen berhak untuk tidak membeli atau mengembalikan barang tersebut jika pedagang salah dalam memberikan informasi.

Menurut analisa penulis mengenai informasi yang diberikan penjual kepada pembeli tidaklah secara benar, jelas dan jujur sesuai dengan kondisi yang janjikan. Karena jarang sekali ditemukan pedagang yang berlaku jujur. Kebanyakan pedagang hanya ingin menghabiskan barang dagangannya dengan berbagai promosi yang mereka lakukan dalam transaksi di pasar. 


\section{Mendapatkan Kompensasi, Ganti Rugi Dan/Atau Penggantian, Apabila Barang Yang Diterima Tidak Sesuai Dengan UTTP}

Dalam praktek dilapangan seringkali ditemukan konsumen yang dijadikan korban dalam aktivitas bisnis para pelaku usaha, salah satunya adalah masalah akurasi timbangan serta kurangnya perhatian para pelaku usaha ini akan kewajibanya. Ketidaktahuan atau tertipunya konsumen terhadap kecurangan pada saat mengukur terlihat ketika pedagang memakai pinggir meja untuk mengukur barang, sehingga tidak diketahui apakah pinggir meja itu telah sesuai dengan ukuran yang sebenarnya atau tidak.

Ada juga pedagang yang melakukan pengukuran dengan meteran namun ditarik sekencang mungkin barang tersebut sehingga ketika barang tersebut mengendur terjadi pengurangan ukuran. Sedangkan kecurangan pada saat menakar ditemukan pada saat pedagang menakar minyak dengan ritme yang sangat cepat, pemakaian takaran bukan standar seperti kaleng susu, ember, dan alat-alat lainnya.

Menurut analisa penulis terhadap praktek kecurangan takaran timbangan oleh pelaku usaha atau pedagang dalam transaksi jual beli, maka konsumen dapat menuntut berupa pengembalian barang atau menukar barang sesuai dengan jaminan mutu, karena mengakibatkan kerugian bagi orang lain. Hasil penyebaran angket penulis kepada responden terkait masalah ganti rugi dimana jawaban responden dapat dilihat pada tabel dinawah ini:

Tabel 8. Konpensasi Dan Ganti Rugi Atas Barang Yang Tidak Sesuai Dengan Perjanjian

\begin{tabular}{llll}
\hline No & Jawaban Responden & Jumlah & Persentase \\
\hline 1 & Ya & 6 & $18.75 \%$ \\
2 & Tidak & 26 & $81.25 \%$ \\
& Jumlah & 32 & $100 \%$ \\
\hline
\end{tabular}

Sumber: Data yang diolah pada bulan Juli-Agustus 2018

Dari tabel diatas dapat dilihat dari keseluruhan responden yang menyatakan mendapatkan konpensasi dan ganti rugi atas barang yang tidak sesuai dengan perjanjian sebanyak 6 responden atau setara dengan $18.72 \%$ dan sebanyak 26 responden atau setara dengan $81.25 \%$ yang menyatakan tidak mendapat kompensasi dan ganti rugi atas barang yang dibeli tidak sesuai dengan perjanjian. Ini membuktikan bahwa pelaku usaha belum menjalankan kewajibannya sebagaimana yang terdapat dalam Undang-Undang.

Banyak konsumen yang mengambil sikap tidak peduli akan hak untuk memperoleh ganti rugi, karena berasumsi bahwa terkurasnya tenaga dan waktu untuk mengurus ganti kerugian yang nilai rupiahnya tidak seberapa. Bahkan ketika konsumen menuntut atas komplain yang di derita kepada para pelaku usaha, yang didapat hanyalah hirauan para pelaku usaha yang tidak memperdulikan nasib dan kerugian konsumen. Akibatnya sangat memperihatinkan hingga saat ini konsumen masih menemukan produk barang dan atau jasa yang tidak memenuhi mutu pelayanan, terutama yang menyangkut mutu barang, pelayanan, serta bentuk transaksi lainnya.

Berdasarkan hasil penyebaran angket penulis kepada pelaku usaha berkaitan dengan pemberian kompensasi dan ganti rugi kepada pembeli (konsumen) yang mengembalikan barang yang sudah dibeli karena tidak sesuai dengan yang dijanjikan, dimana jawaban responden dapat dilihat pada tabel dibawah ini:

Tabel 9. Pemberian Kompensasi Dan Ganti Rugi Atas Barang Kepada Konsumen

\begin{tabular}{llll}
\hline No & Jawaban Responden & Jumlah & Persentase \\
\hline 1 & Ya & 5 & $31.25 \%$ \\
2 & Tidak & 11 & $68.75 \%$ \\
& Jumlah & 16 & $100 \%$ \\
\hline
\end{tabular}

Sumber: Data yang diolah pada bulan Juli-Agustus 2018

Dari tabel diatas dapat dilihat dari keseluruhan responden yang menyatakan tentang pemberian konpensasi dan ganti rugi atas barang kepada konsumen, sebanyak 31.25\% atau setara dengan 5 orang responden yang menjawab Ya sedangkan sebanyak $68.75 \%$ atau setara dengan 11 orang responden yang menjawab Tidak memberikan konpensasi dan ganti rugi kepada konsumen atas barang yang sudah dibeli. Ini 
membuktikan bahwa pelaku usaha hanya ingin merauk keuntungan dari dagangannya tanpa memperhatikan hak konsumen.

Hasil wawancara penulis kepada salah seorang pelaku usaha juga menyatakan bahwa barang yang sudah dibeli tidak boleh dikembalikan, namun konsumen bisa saja menukar dengan barang lain sesuai dengan kesepakatan baru. Beginilah posisi konsumen di lapangan jika meminta ganti kerugian atas barang yang sudah dibeli. Hal ini dikarenakan konsumen yang meminta ganti kerugian tidak pada saat akad jual beli terjadi, melainkan pada saat setelah terjadinya akad jual beli

Pasal 19 Undang-Undang Perlindungan Konsumen mengharuskan pelaku usaha bertanggungjawab terhadap:

a. Pelaku usaha bertanggungjawab memberikan ganti rugi atas kerusakan, pencemaran, dan/atau jasa yang dihasilkan atau diperdagangkan.

b. Ganti rugi sebagaimana dimaksud pada ayat (1) dapat berupa pengembalian uang atau penggantian barang dan/atau jasa yang sejenis atau setara nilainya, atau perawatan kesehatan dan/atau pemberian santunan yang sesuai dengan ketentuan peraturan perundang-undangan yang berlaku.

c. Pemberian ganti rugi dilaksanakan dalam tenggang waktu 7(tujuh) hari setelah tanggal transaksi.

d. Pemberian ganti tugi sebagaimana dimaksud pada ayat (1) dan ayat (2) tidak menghapuskan kemungkinan adanya tuntutan pidana berdasarkan pembuktian lebih lanjut mengenai adanya unsur kesalahan.

e. Ketentuan sebagaimana dimaksud pada ayat (1) dan ayat (2) tidak berlaku apabila pelaku usaha dapat membuktikan bahwa kesalahan tersebut merupakan kesalahan konsumen.

Hak atas ganti kerugian ini dimaksud untuk memulihkan keadaan yang menjadi rusak (tidak seimbang) akibat adanya penggunaan barang atau jasa yang tidak memenuhi harapan konsumen. Hak ini sangat terkait dengan penggunaan produk yang telah merugikan konsumen, baik yang berupa kerugian materiil, maupun kerugian yang menyangkut diri (sakit, cacat, bahkan kematian) konsumen.

Menurut penulis bahwa konsumen memiliki hak penuh untuk mendapatkan ganti kerugian karena untuk mendapatkan ganti rugi sudah dijamin dalam Pasal 19 Undang-Undang Perlindungan Konsumen dimana menyatakan bahwa pelaku usaha bertanggunjawab memberikan ganti rugi atas kerusakan dan atau kerugian tersebut dapat berupa pengembalian uang atau penggantian barang yang sejenis atau setara nilainya.

Namun dalam praktek di lapangan masih ditemukan pelaku usaha yang enggan menberikan kompensasi dan ganti rugi atas barang yang diperdagangkan yang tidak sesuai dengan UTTP. Menurut analisa penulis hal ini dikarenakan pelaku usaha hanya ingin mengambil keuntungan tanpa memperhatikan aturan hukum yang timbul atas transaksi perdagangan yang telah dilakukan.

Pasal 19 Undang-Undang Perlindungan Konsumen (UUPK) mengharuskan pelaku usaha bertanggungjawab terhadap:

a. Pelaku usaha bertanggung jawab memberikan ganti rugi atas kerusakan, pencemaran, dan/atau kerugian konsumen akibat mengkonsumsi barang dan/atau jasa yang dihasilkan atau diperdagangkan.

b. Ganti rugi sebagaimana dimaksud pada ayat (1) dapat berupa pengembalian uang atau penggantian barang dan/atau jasa yang sejenis atau setara nilainya, atau perawatan kesehatan dan/atau pemberian santunan yang sesuai dengan ketentuan peraturan perundang-undangan yang berlaku.

c. Pemberian ganti rugi dilaksanakan dalam tenggang waktu 7 (tujuh) hari setelah tanggal transaksi.

d. Pemberian ganti rugi sebagaimana dimaksud pada ayat (1) dan ayat (2) tidak menghapuskan kemungkinan adanya tuntutan pidana berdasarkan pembuktian lebih lanjut mengenai adanya unsur kesalahan.

e. Ketentuan sebagaimana dimaksud pada ayat (1) dan ayat (2) tidak berlaku apabila pelaku usaha dapat membuktikan bahwa kesalahan tersebut merupakan kesalahan konsumen.

Hak atas ganti kerugian ini dimaksud untuk memulihkan keadaan yang telah menjadi rusak (tidak seimbang) akibat adanya penggunaan barang atau jasa yang tidak memenuhi harapan konsumen. Hak ini sangat terkait dengan penggunaan produk yang telah merugikan konsumen, baik yang berupa kerugian materil, maupun kerugian yang menyangkut diri (sakit, cacat, bahkan kematian) konsumen.

Menurut penulis bahwa konsumen memiliki hak penuh untuk mendapatkan ganti kerugiaan, karena untuk mendapatkan ganti rugi sudah dijamin dalam pasal 19 Undang-Undang Perlindungan Konsumen dimana menyatakan bahwa pelaku usaha bertanggung jawab memberikan ganti rugi atas kerusakan dan atau 
kerugian akibat barang yang diperdagangkan, yang mana ganti kerugian tersebut dapat berupa pengembalian uang, atau penggantian barang yang sejenis atau setara nilainya.

Namun dalam praktek dilapangan masih ditemukan pelaku usaha yang enggan memberikan kompensasi dan ganti rugi atas barang yang diperdagangkan yang tidak sesuai dengan UTTP. Menurut analisa penulis hal ini dikarenakan pelaku usaha hanya ingin mengambil keuntungan tanpa memperhatikan aturan hukum yang timbul atas transaksi perdaganagan yang telah dilakukan.

\section{Faktor Pendukung, Kendala, dan Upaya Hukum}

Perlindungan konsumen yang dijamin oleh Undang-Undang ini adalah adanya kepastian hukum terhadap segala perolehan kebutuhan konsumen. Kepastian hukum ini meliputi segala upaya berdasarkan hukum untuk memberdayakan konsumen memperoleh atau menentukan haknya apabila dirugikan oleh pelaku usaha penyedia kebutuhan konsumen tersebut. Metrologi legal mempunyai peranan yang sangat penting dalam upaya peningkatan perlindungan terhadap konsumen dan produsen dalam menciptakan iklim usaha yang kondusif, melalui UndangUndang Nomor 2 Tahun 1981 tentang Metrologi Legal menyebutkan beberapa perbuatan yang dilarang yang diatur pada pasal 25 yaitu:

Dilarang mempunyai, menaruh, memamerkan, memakai atau menyuruh memakai

1. alat-alat ukur, takar, timbang dan atau perlengkapannya yang bertanda batal;

2. alat-alat ukur, takar, timbang dan atau perlengkapannya yang tidak bertanda tera sah yang berlaku atau tidak diserta keterangan pengesahan yang berlaku, kecuali seperti yang disebut dalam Pasal 12 huruf $b$ Undang-Undang ini;

3. alat-alat ukur, takar, timbang, dan atau perlengkapannya yang tanda teranya rusak alat-alat ukur, takar, timbang dan atau perlengkapannya yang tidak bertanda tera sah yang berlaku atau tidak disertai keterangan pengesahan yang berlaku, kecuali seperti yang tersebut dalam Pasal 12 huruf b Undangundang ini;

4. alat-alat ukur, takar, timbang, dan atau perlengkapannya yang setelah padanya dilakukan perbaikan perubahan yang dapat mempengaruhi panjang, isi, berat, atau penunjukkannya yang sebelum dipakai kembali tidak disahkan oleh pegawai yang berhak;

5. alat-alat ukur, takar, timbang, dan atau perlengkapannya yang panjang, isi, berat, atau penujukannya menyimpang dari nilai yang seharusnya daripada yang diizinkan berdasarkan Pasal 12 huruf c undangundang ini untuk tera ulang;

6. alat-alat ukur, takar, timbang, dan atau perlengkapannya yang mempunyai tanda khusus yang memungkinkan orang menentukan ukuran, takaran, atau timbangan menurut dasar dan sebutan lain daripada yang dimaksud dalam Pasal 6 dan Pasal 7 undang-undang ini;

7. alat-alat ukur, takar, timbang dan atau perlengkapannya untuk keperluan lain daripada yang dimaksud dalam atau berdasarkan undang-undang ini; di tempat usaha; di tempat untuk menentukan ukuran atau timbangan untuk kepentingan umum; di tempat melakukan penyerahan-penyerahan; di tempat menentukan pungutan atau upah yang didasarkan pada ukuran atau timbangan.

Dalam upaya untuk melindungi hak-hak konsumen terhadap pelanggaran yang dilakukan pelaku usaha, Undang-Undang No. 8 Tahun 1999 tentang Perlindungan Konsumen, ada 10 (sepuluh) larangan bagi pelaku usaha sesuai dengan ketentuan Pasal 8 ayat (1) UUPK, yakni pelaku usaha dilarang memproduksi dan atau memperdagangkan barang dan atau jasa yang :

a. Tidak memenuhi tidak sesuai dengan standar yang dipersyaratkan dan ketentuan peraturan perundangundangan.

b. Tidak sesuai dengan berat bersih, isi bersih atau netto, dan jumlah dalam hitungan sebagaimana yang dinyatakan dalam label atau entiket barang tersebut.

c. Tidak sesuai dengan ukuran, takaran, timbangan, dan jumlah dalam hitungan menurut ukuran yang sebenarnya.

d. Tidak seusia dengan kondisi jaminan, keistimewaan, atau kemanjuran sebagaimana dinyatakan dalam label, etiket, atau keterangan barang dan atau jasa tersebut.

e. Tidak sesuai dengan mutu, tingkatan, komposisi, proses pengolahan, gaya, mode, atau penggunaan tertentu sebagaimana dinyatakan dalam label atau keterangan barang dan atau jasa tersebut.

f. Tidak sesuai dengan janji yang dinyatakan dalam label, etiket, keterangan, iklan atau promosi penjualan barang atau jasa tersebut. 
g. Tidak mencantumkan tanggal kadaluwarsa atau jangka waktu penggunaan/pemanfaatan yang paling baik atas barang tertentu.

h. Tidak mengikuti ketentuan berproduksi secara halal, sebagaimana pernyataan halal yang dicantumkan dalam label.

i. Tidak memasang label atau membuat penjelasan barang yang memuat nama barang, ukuran, berat/isi bersih atau netto, komposisi, aturan pakai, tanggal pembuatan, akibat sampingan, nama dan alamat pelaku usaha serta keterangan lain untuk penggunaan yang menurut ketentuan harus dipasang atau dibuat.

j. Tidak mencantumkan informasi dan atau petunjuk penggunaan barang dalam bahasa Indonesia sesuai dengan ketentuan perundang-undangan yang berlaku.

Peraturan hukum yang melindungi konsumen tidak dimaksud untuk mematikan usaha para pelaku usaha, tetapi justru sebaliknya perlindungan konsumen dapat mendorong iklim berusaha yang tangguh dalam menghadapi persaingan melalui penyediaan barang-barang dan atau jasa yang berkualitas.

Pembentukan Undang-Undang tentang Perlindungan Konsumen merupakan langkah positif pemerintah dalam mengimplementasikan aspirasi masyarakat konsumen. Namun demikian undang-undang yang bagus tersebut tidak akan berarti jika tidak didukung oleh pelaksanaan yang bagus pula. Untuk mewujudkan suatu sistem perlindungan konsumen yang efektif, sangat diperlukan komitmen dari aparat penegak hukum untuk dapat melaksanakan tugasnya secara konsisten dan bersungguh-sungguh.

Berdasarkan hasil wawancara penulis pada hari selasa tanggal 8 Oktober 2018, kepada Dinas Perindusrtian dan Perdagangan kota Kota Palu pada bidang Perdagangan yaitu bapak Sudirman menyatakan bahwa mengawasi UTTP pada pedagang Pasar Tradisional Kota Palu memang merupakan wewenang Dinas Perindustian Dan Perdagangan, yang sebelumnya merupakan wewenang Unit Pelaksanaan Teknis Kemetrologian.

Namun setelah beralih status menjadi Unit Kerja danUnit Pelaksana Teknis Daerah (UPTD) yang berada dibawah naungan Disperindag, beberapa fungsi dalam layanan kemetrologian utamanya fungsi pengawasan dan penindakan menjadi kewenangan Dinas Perindustrian dan Perdagangan Kota Kota Palu.

Sebagai antisipasi terhadap kecurangan penggunaan UTTP oleh para pedagang serta untuk melindungi dan memberikan kepastian berat terhadap barang/komodi belanjaan para pembeli/konsumen melalui kegiatan ini, maka Disperindag memfasilitasi penyediaan Pos Ukur Ulang di pasar-pasar tradisional dengan tujuan para pembeli dapat menguji kembali barang belanjaannya pada Pos Ukur Ulang ini. Namun dikarenakan kurangnya anggaran biaya dari APBD tidak semua pasar tradisional yang tersedia Pos Ukur Ulang termasuk pasar Tradisional.

Berdasarkan wawancara penulis kepada ketua Disperindag kota Kota Palu menyatakan untuk membantu para konsumen yang kurang percaya dan merasa di rugikan oleh pedagang jika nantinya di temukan akan timbangan yang tidak sesuai dengan pembelian, konsumen bisa langsung komplain ke pedagangnya. Konsumen yang merasa dirugikan karena tidak terpenuhi hak-haknya sebagaimana yang dilindungi oleh Undang-Undang Nomor 8 Tahun 1999 Tentang Perlindungan Konsumen dapat mengajukan gugatan baik melalui pengadilan maupun diluar pengadilan. Ini salah satu bentuk kepedulian kepada ibu khususnya dan pembeli umumnya. Selain juga untuk perlindungan konsumen dari ketidakjujuran timbangan pedagang.

Pelayanan kemetrologian pada Unit Pelaksana Teknis metrologi legal Dinas Perindustrian dan Perdagangan Kota Palu sudah berlangsung sejak tahun 2010. Namun dalam pelaksanaan penerapan tera dan tera ulang UTTP pada UPTD Metrologi Kota Palu masih mengalami kendala di beberapa faktor pelayanan antara lain:

1. Pelaksanaan tera dan tera ulang di Kota Kota Palu masih dilaksanakan bekerjasama dengan UPT Metrologi Dinas Perindustrian dan Perdagangan Provinsi Riau.

2. Tempat pelaksanaan tera dan tera ulang UTTP di pasar-pasar tradisional belum memadai.

3. Anggaran yang tersedia belum memadai jika dibandingkan dengan potensi UTTP yang ada di Kota Kota Palu.

4. Kesadaran pemilik UTTP masih rendah terhadap arti pentingnya tera dan tera ulang yang dilakukan pada setiap tahunnya.

5. Pelaksanaan tera dan tera ulang yang dilakukan bersamaan dengan waktu potensial pemilik UTTP melakukan kegiatan perdagangan. 
6. Banyaknya beredar UTTP yang dilarang untuk digunakan didalam transaksi perdagangan (timbangan plastik). Kurangnya sosialisasi kebijakan dan pengetahuan wajib tera pada pedagang pasar tradisional.

7. Kurangnya kerja sama dari konsumen, pelaku usaha dan lembaga pemerintah.

8. Sanksi yang diberikan belum memberi efek jera bagi pelaku usaha pasar tradisional yang tidak tertib UTTP.

Permasalahan lain yang menjadi faktor penghambat dalam pelaksanaan pelayanan tera dan tera ulang pada UPT Metrologi Legal adalah peralatan standar yang digunakan untuk melakukan tera dan tera ulang yang belum memadai. Sehingga hal ini mengakibatkan proses pelayanan tera dan tera ulang belum berlangsung secara efektif.

Disadari bahwa tugas-tugas yang dihadapi oleh Disperindag semakin luas dan kompleks. sementara secara organisasi (kelembagaan, sistem, struktur, perilaku/budaya kerja), Disperindag masih sangat terbatas dibandingkan dengan ruang lingkup maupun cakupan tugas yang terus berkembang. Keterbatasan organisasi ini telah mendorong Disperindag untuk terus meningkatkan efisiensi dan efektifitas dalam penyelenggaraan seluruh program yang ada.

Hasil wawancara penulis kepada salah seorang pedagang mengatakan dalam hal pengawasan pasar yang dilakukan disperindag untuk saat sekarang ini belum adanya tindakan tegas atau berupa sanksi yang diberikan kepedagang yang melanggar ketentuan undang - undang, namun Disperindang hanya memberitahukan dalam bentuk teguran kepada kami. 16 menurut bapak Sudirman jika tidakan pelaku usaha pasar tradisional ini diproses keranah hukum, kasihan bagi pelaku usahanya karena besarnya biaya proses perkara yang tidak sesuai dengan keuntungan yang didapat, serta pelaku usaha ini juga tidak dapat menjalankan usahanya.

Menurut analisa penulis sebenarnya permasalahan ini harus ditegakkan dengan adil. Namun kenyataannya saat ini konsumen merasa dirugikan karena adanya praktek perdagangan dengan korupsi timbangan, sedangkan konsumen telah membayar sesuai dengan kesepakatan, praktek seperti ini telah merampas hak orang lain (konsumen).

Dalam praktek dilapanganpun belum ditemukan adanya tindakan tegas yang diambil oleh disperindag maupun Pemerintah untuk melindungi hak-hak konsumen dan konsumen dalam melindungi dirinya sendiri. lemahnya upaya penegakan hukum terhadap pelanggaran maka dapat disimpulakn bahwa perlindungan terhadap konsumen masih lemah, posisi konsumen sering dirugikan dan lemahnya pengawasan penerapan UTTP terhadap pasar-pasar tradisional. Adapun solusi yang dapat dilakukan dalam pengawasan pelaksanaan penerapan tera dan tera ulang UTTP pada UPTD Metrologi Kota Palu:

1. Bekerjasama dengan UPTD Dinas Pasar untuk menyediakan tenda dan atau los yang ada di pasar-pasar tradisional

2. Mengupayakan penambahan anggaran pada tahun-tahun berikutnya.

3. Petugas (panitia) beserta pengamat tera dari UPT Metrologi langsung memfasilitasi pemilik tera untuk melakukan tera terhadap UTTP yang dimilikinya.

4. Memprogramkan penggantian timbangan plastik pada tahun-tahun berikutnya yang dipergunakan dalam transaksi perdagangan pada pasar-pasar tradisional.

5. Mengambil tindakan tegas atas pelanggaran UTTP

\section{Upaya Pemerintah Dalam Menangani Praktek Penyimpangan Metrologi}

Penegakan hukum adalah upaya untuk tegaknya atau berfungsinya norma-norma hukum secara nyata sebagai pedoman perilaku dalam hubungan hukum dalam kehidupan bermasyarakat dan bernegara. Siapa saja yang menjalankan aturan normatif atau melakukan sesuatu atau tidak melakukan sesuatu dengan berdasarkan daripada norma atau aturan hukum yang berlaku, berarti dia menjalankan atau menegakkan aturan hukum. Dalam arti sempit dari segi subjeknya penegakan hukum tertentu untuk menjamin dan memastikan bahwa aturan hukum itu, apabila diperluka, aparatur penegak hukum itu diperkenankan untuk menggunakan daya paksa ${ }^{11}$.

Uraian diatas dapat ditarik kesimpulan bahwa hukum merupakan bagian dari kebudayaan suatu masyarakat, maka hukum tidak dapat dipisahkan dari jiwa serta cara berpikir masyarakat, atau hukum merupakan suatu struktur rohaniyah suatu msyarakat. Untuk memfungsikan kaidah hukum maka diperlukan

${ }^{11}$ Jimly Asshiddique, Penegakan Hukum. http://www.jimly.com/kegiatan/show/419?page=23 
upaya-upaya hukum agar penegakan hukum dapat tercapai antara lain secara preventif dan represif. Upaya hukum secara preventif antara lain:

a. Segala usaha dan kegiatan di bidang penegakan metrologi legal preventif dalam bentuk usaha memelihara situasi yang ada dan mencegah segenap kemungkinan-kemungkinan akan terjadinya penyimpanganpenyimpangan, pelanggaran peraturan, hukum, dan perundang-undangan serta berbagai macam bentuk tindak pidana, contohnya :

1. Mengadakan penyuluhan kaitannya dalam bidang metrologi legal agar masyarakat mengetahui secara jelas bagaimana aturannya dan aturan menurut undang-undang yang berlaku sehingga masyarakat tidak merasa asing mendengar tera ulang metrologi legal.

2. Melaksanakan pengelolaan standar ukuran dan laboratorium kemetrologian.

3. Melaksanakan pengawasan UTTP dan BDKT (barang dalam keadaan terbungkus)

b. Upaya hukum kedua yakni upaya hukum represif segala usaha dan kegiatan di bidang metrologi legal represif dalam rangka penegakan hukum pada umumnya, penyelidikan dan penyidikan secara tuntas dalam rangka mata rantai sistem acara pidana, contohnya:

1. Mengadakan operasi pasar untuk alat ukur, takar, timbang yang digunakan pedagang untuk menakar barang yang diperjualbelikan dengan tujuan untuk menertibkan, dan memberikan perlindungan kepada konsumen.

2. Menandai dengan tanda tera sah atau tera batal yang berlaku, atau memberikan keterangan-keterangan tertulis yang bertanda tera sah atau tera batal yang berlaku, dilakukan oleh pegawai-pegawai yang berhak melakukannya berdasarkan pengujian yang dijalankan atas alat ukur, timbang, takar, dan perlengkapannya yang belum dipakai.

3. Pembubuhan tanda sah pada alat-alat ukur, takar, timbang, dan perlengkapannya yang disahkan pada waktu ditera ulang. Pemasangan tanda sah dimulai pada tanggal 1 Januari sampai dengan 31 Desember tahun yang bersangkutan dan meter kWh berlaku 10 (sepuluh) tahun, tanda batal dibubuhkan pada alat-alat ukur, timbang, takar dan perlengkapannya yang dibatalkan atau yang tidak memenuhi persyaratan tenis pada waktu ditera ulang.

4. Tindakan hukum bagi orang atau badan hukum yang melakukan tindak pidana metrologi legal sesuai undang-undang metrologi legal melalui aparat penegak hukum.

Upaya-upaya hukum baik secara preventif maupun represif diatas diharapkan agar masyarakat sadar akan hukum metrologi legal sehingga terlaksana atau ketertiban hukum dan kepercayaan konsumen terhadap para pedagang atau pengusaha yang menggunakan alat ukur, takar, timbang, dan perlengkapannya.

Untuk dapat menegakkan hukum yang dicita-citakan oleh masyarakat, negara dan bangsa, diperlukan penyelesaian terhadap beberapa pertanyaan pendahukuan, apakah hukum yang akan ditegakkan sudah mengandung nilai-nilai yang berdasar atas landasan sumber tertib hukum sebagaimana terkandung dalam Pancasila dan UUD 1945, apakah aparatur negara yang ditugasi menegakkan norma-noma hukum yang sumber dan dasarnya terkandung dalam Pancasila dan UUD 1945, dan akhirnya apakah masyarakat yang akan diayomi oleh hukum yang ditegakkan sudah berkeyakinan bahwa nilai-nilai hukum yang dilaksanakan penegakannya oleh para penegak hukum itu sudah sesuai dengan dasar falsafah negara dan bangsa yang telah diterima oleh seluruh masyarakat yakni sesuai dengan nilai-nilai Pancasilan dan UUD 1945.

Penegakan hukum merupakan bagian dari suatu bangsa untuk mmempertahankan eksistensinya melalui pengorganisasian sumber-sumber daya guna merealisasikan cita-cita dan citra masyarakat yang terkandung dalam tata hukumnya. Oleh karena itu di dalam pembicaraan mengenai masalah penegakan hukum itu kita berhadapan dengan beberapa faktor yakni :

1. Nilai-nilai yang dipertahankan dalam masyarakat atau negara bukanlah merupakan suatu kehidupan bersama yang berjalan tanpa mengandung penghayatan akan nilai-nilai tertentu. Dalam berhadapan dengan dunia nilai-nilai ini, bangsa Indonesia menghayatinya dalam bentuk suatu struktur tertentu, yaitu : Pancasila, sistem nilai-nilai inilah yang secara sistematis mengatakan kegiatan-kegiatan dalam masyarakat.

2. Struktur atau sistem kelembagaan dalam masyarakat yang diciptakan untuk mengorganisasi sumbersumber daya guna mempertahankan eksistensi masyarakat. Salah satu aspek adalah mempertahankan ketertiban. Ketertiban di Indonesia mempunyai ciri-ciri tersendiri sebagai akibat dari hubungan sibernetisnya dengan sistem nilai-nilai, yaitu Pancasila sebagaimana tersebut pada butir 1 diatas. Sistem 
penegakan hukum di Indonesia bisa kita lihat sebagai suatu struktur atau sistem kelembagaan yang diciptakan untuk mengorganisasi sumber-sumber daya sebagaimana disebutkan di muka.

3. Kegiatan-kegiatan lain yang dilakukan untuk mempertahankan eksistensi masyarakat secara vital, berupa ekonomi dan politik. Kegiatan-kegiatan ini mempunyai hubungan sibernetis pula dengan sistem penegakan hukum. Dalam arti bahwa sistem penegakan hukum itu mengontrol bekerjanya kegiatankegiatan tersebut. Oleh karena kegiatan-kegiatan ekonomi dan politik mempunyai energi yang lebih besar, maka kegiatan-kegiatan tersebut pada gilirannya menentukan bagaimana penegakan hukum itu bisa dijalankan. Sudah sering kita menyaksikan betapa politik dan kekuasaan di suatu negeri menentukan bagaimana hukum dijalankan. Adapun pengaruh kegiatan ekonomi bisa mempunyai arti penting bagi jalannya penegakan hukum di suatu negara.

Penegakan hukum dalam tindak pidana metrologi legal berkaitan dengan putusan hakim dimana dalam Pasal 1 butir 11 KUHAP disebutkan bahwa putusan pengadilan didefinisikan sebagai pernyataan hakim yang diucapkan dalam sidang pengadilan terbuka, yang dapat berupa pemidanaan atau bebas, atau lepas dari segala tuntutan hakim dalam hal serta menurut cara yang diatur dalam undang-undang ini.

Dalam menjatuhkan putusan pada dasarnya putusan hakim mempunyai peranan yang menentukan hukum dan keadilan. Oleh karena itu di dalam menjatuhkan putusannya hakim diharapkan agar selalu berhati-hati. Hal ini dimaksudkan untuk menjaga agar jangan sampai suatu putusan penuh dengan kekeliruan yang akibatnya akan menimbulkan rasa tidak puas, ketidakadilan, dan dapat menjatuhkan kewibawaan pengadilan.

Metrologi itu sendiri mempunyai arti sebagai ilmu yang mempelajari masalah pengukuran. Ketentuan kaidah hukum dalam kegiatan berdagangan mempergunakan ukuran, takaran, timbangan, dan perlengkapannya (UTTP) selanjutnya dipergunakan istilah timbangan yang telah diatur dalam UndangUndang No. 2 Tahun 1981 tentang Metrologi Legal.

Penegakan hukum tentang tindak pidana metrologi legal yakni pertama dengan cara menegur, kedua dengan cara merampas barang pelaku berdasarkan Pasal 39 KUHP tentang perampasan yakni:

1. Barang-barang kepunyaan terdakwa yang diperoleh dari kejahatan atau sengaja dipergunakan untuk kejahatan, dapat dirampas.

2. Dalam hal pemidanaan karena kejahatan dapat dilakukan dengan sengaja, atau karena pelanggaran, dapat juga dirampas seperti diatas, tetapi hanya dalam hal-hal yang ditentukan dalam Undang-Undang.

3. Perampasan dapat juga dilakukan terhadap orang yang bersalah yang oleh hakim diserahkan kepada pemerintah, tetapi hanya atas barang-barang yang telah disita.

Dan yang ketiga, yakni dengan memberikan sanksi berdasarlan Pasal 2 Undang-Undang No. 2 Tahun 1981 tentang Metrologi Legal sebagai berikut :

1. Barang siapa melakukan perbuatan yang tercantum dalam Pasal 25, Pasal 26, Pasal 27, dan Pasal 28 Undang-Undang ini dipidana penjara selama-lamanya 1 (satu) tahun dan atau denda setinggi-tingginya Rp. 1.000.000,- (satu juta rupiah).

2. Barang siapa melakukan perbuatan yang tercantum dalam Pasal 30 dan Pasal 31 Undang-Undang ini dipidana penjara selama-lamanya 6 (enam) bulan atau denda setinggi-tingginya Rp. 500.000,- (lima ratus ribu rupiah).

3. Pelanggaran terhadap perbuatan yang tercantum dalam Pasal 22, Pasal 23, Pasal 29 ayat (1) dan ayat (3) Undang-Undang ini dipidana kurungan selama-lamanya 6 (enam) bulan atau denda setinggi-tingginya Rp. 500.000,- (lima ratus ribu rupiah)

\section{DAFTAR PUSTAKA}

Achmad Ali, 1998., Menjelajahi Kajian Empiris Terhadap Hukum, Yasrif Watampone, Jakarta; Atabaiq Ali, 2003., Kamus Kontemporer Arab-Indonesia, Multi Karya Grafika, Yogyakarta; Moestadji., 1991., Tinjauan Umum Hukum Lingkungan Hidup dalam Penindakan Pelanggaran Hukum Lingkungan, Prosiding Lokakarya, Kantor Meneg KLH bekerjasama dengan EMDI, Jakarta.

Philipus M. Hadjon., 1992., "Perlindungan Hukum bagi Rakyat Rakyat Indonesia, sebuah Studi tentang Prinsip-prisipnya, Penanganannya oleh Pengadilan Umum dan Pembentukan Peradilan Administrasi Negara". Bina Ilmu, Surabaya; 
Ridwan Tahir., 2012 "Perlindungan Hukum Kawasan Hutan Konservasi, Studi tentang Penegakan Hukum Pidana Lingkungan pada Kawasan Taman Nasional”, Disertasi , Program Pascasarjana Universitas Hasanuddin, Makassar;

Sunaryati Hartono., 1969., “Apakah The Rule of Law Itu?”. Alumni, Bandung.;

Al-Qur'an, Surah Al-An'am, Ayat 152;

Alkitab Online.;

https://www.rappler.com/indonesia/125058-5-hal-tera-timbangan-penting-jangan curang.

https://id.wikipedia.org/wiki/Timbangan

http://www.berbagaireviews.com/2017/11/pengertian-timbangan-dan-jenis-jenis.html

Undang-undang Nomor. 2 Tahun 1981 tentang Metrologi Legal.;

Peraturan Pemerintah Nomor 26 Tahun 1983 tentang Tarip biaya Tera;

Peraturan Pemerintah Nomor. 2 Tahun 1985 tentang Wajib dan Pembebasan untuk Ditera/atau Ditera Ulang Serta Syarat-syarat Bagi Alat-alat Ukur, Takar, Timbang, dan Perlengkapannya;

Peraturan Pemerintah Nomor. 10 Tahun 1989 tentang Satuan Turunan, Satuan Tambahan, dan Satuan Lain yang Berlaku;

Keputusan Menteri Perindustrian dan Perdagangan Republik Indonesia Nomor. 61/MPP/Kep/2/1998 tentang Penyelenggaraan Kemetrologian, sebagaimana telah diubah dengan Keputusan Menteri Perindustrian dan Perdagangan Republik Indonesia Nomor. 251/MPP/Kep/6/1999. 